\title{
Connective tissue disease due to intentional inhalation of scouring powder
}

\author{
M. Vincent*, C. Pouchelle*, S. Martinon*, F. Gerard**, Y. Arthaud**
}

\begin{abstract}
Connective tissue disease due to intentional inhalation of scouring powder. M. Vincent, C. Pouchelle, S. Martinon, F. Gerard, Y. Arthaud. (C) ERS Journals Ltd 1996.

ABSTRACT: There have been reports in the literature of acute and chronic silicosis and connective tissue disease induced by occupational exposure to silica in factories producing scouring powder. Reports of connective tissue diseases induced by intentional inhalation of such a powder are rare and perhaps underestimated.

We report the case of a young woman who developed Sharp's syndrome 5 yrs after diagnosis of acute silicosis due to scouring powder inhalation. The frequency of diseases from scouring powder as well as physiopathological and therapeutical issues of the associatition of pneumoconiosis and connective tissue disease are discussed.
\end{abstract}

Eur Respir J., 1996, 9, 2688-2690.
*Centre Hospitalier St Joseph et St Luc, Lyon, France. **Institut Pastuer, Lyon, France. Correspondence: M. Vincent

Centre Hospitalier St Joseph et St Luc 9 rue Pr Grignard

Lyon 69007

France

Keywords: Acute silicosis, connective tissue disease, energy-dispersive X-ray analysis, scouring powder, whole lung lavage

Received: January 31996

Accepted after revision June 261996
In 1989, we examined a 20 year old woman with acute silicosis due to inhalation of scouring powder (Ajax cleaner, Colgate Palmolive Co.) [1]. A single case of silicosis has been reported previously, with long-term survival and vasculitic sequelae following such an inhalation [2]. The patient improved after corticotherapy, but was lost from sight until a mixed connective disease arose, which we now describe.

\section{Case report}

A 25 year old woman was admitted to hospital in January 1994 with asthenia, weight loss of $15 \mathrm{~kg}$ in 6 months, fever, myalgias and Raynaud's syndrome. Chest examination revealed bilateral end-inspiratory crackles. Sclerodactyly and amyotrophia were noted. Chest radiography and scan (figs. 1 and 2) showed an increase of the interstitial infiltrate, extending to the upper lobes, in comparison with a stable basilar interstitial infiltration noticed at the last consultation in December 1989. Spirometry also showed a pure restrictive defect with a $50 \%$ reduction of total lung capacity, an increase from the previous measurement in December (29\% reduction). Single-breath transfer factor of the lung for carbon monoxide (TL,CO) was reduced to $40 \%$ of predicted. At rest, determination of arterial blood gas values in room air showed a $\mathrm{pH}$ of 7.48 , arterial carbon dioxide tension $\left(\mathrm{Pa}_{\mathrm{a}} \mathrm{CO}_{2}\right)$ of $4.8 \mathrm{kPa}$, and arterial oxygen tension $\left(\mathrm{Pa}, \mathrm{O}_{2}\right)$ of $10.9 \mathrm{kPa}$.

Laboratory findings were as follows: normal total and differential white blood count (WBC); anaemia, with a haemoglobin level of $10.2 \mathrm{~g} \cdot \mathrm{L}^{-1}$; microcytosis of 71.1 $\mu^{3}$ and normosideraemia; erythrocyte sedimentation rate (ESR) $70 \mathrm{~mm} \cdot \mathrm{h}^{-1}$; polyclonal hypergammaglobulinaemia of $34 \mathrm{~g} \cdot \mathrm{L}^{-1}$; normal serum creatinine; lactate dehydrogenase $(\mathrm{LDH}) 1,776 \mathrm{IU} \cdot \mathrm{L}^{-1}$ (normal range (NR) 221-423 IU $\left.\cdot \mathrm{L}^{-1}\right)$; creatinine phosphokinase $(\mathrm{CPK})$ of 1,294

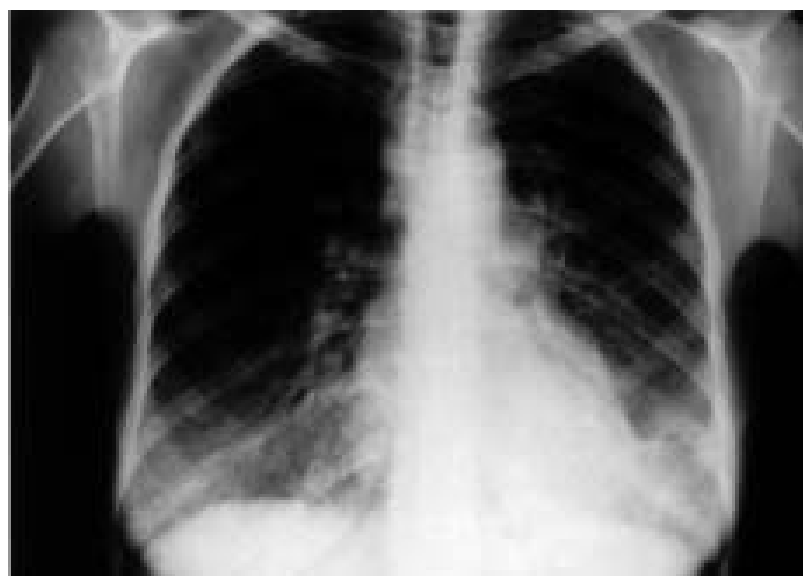

Fig. 1. - Radiographic image of the chest in January 1994, showing predominantly basilar alveolo-interstitial opacities in both lungs.

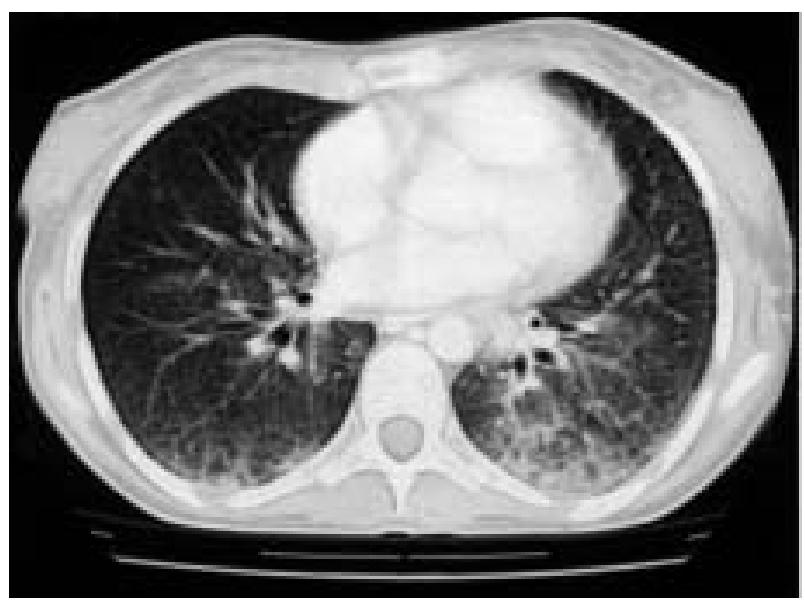

Fig. 2. - Computed tomography scan of the chest in January 1994, showing bilateral reticulonodular infiltrates. 
IU·L-1 (NR 30-186 IU $\left.\cdot \mathrm{L}^{-1}\right)$. Serum glutamic oxaloacetic transaminases (SGOT) of $116 \mathrm{IU} \cdot \mathrm{L}^{-1}$ (NR 10$\left.42 \mathrm{IU} \cdot \mathrm{L}^{-1}\right)$ and serum glutamic pyruvic transaminases (SGPT) of $144 \mathrm{IU} \cdot \mathrm{L}^{-1}\left(\mathrm{NR} 5-60 \mathrm{IU} \cdot \mathrm{L}^{-1}\right)$ were elevated. However, bilirubin and alkaline phosphatase were normal. Prothrombin was 59\%. Serological tests for hepatitis $\mathrm{A}, \mathrm{B}$ and $\mathrm{C}$ were negative. Circulating immune complexes (CIC) were increased to $35 \%$ (NR <4.7). Multiple blood, urine, and sputum cultures were sterile. Antinuclear antibodies (ANA) were increased to 1/4,096 with positive antinuclear antiribonucleoprotease.

Microscopic capillaroscopy showed dermic microvascularitis and capillary ectasies. Electromyography showed a diffuse sensory-motor neuropathy. On fiberoptic bronchoscopy, an inflammatory tracheobronchial tree was seen. Transbronchial lung biopsy showed interstitial fibrosis with inflammation, but without epithelioid granuloma and birefringent particles. Bronchoalveolar lavage (BAL) of the middle lobe was performed. A cloudy fluid was recovered, with $360 \times 10^{-9}$ cells $\cdot \mathrm{L}^{-1}$ containing $68 \%$ macrophages, $30 \%$ neutrophils and $2 \%$ lymphocytes. Energy-dispersive X-ray analysis (EDXA) confirmed the presence of dust particles, with one silicon peak identified as silica within macrophages. Liver biopsy was performed. Histologically, minor signs of acute hepatitis and portal fibrosis were present, but EDXA also showed the presence of silica. Immunostaining for antibody anti$\mathrm{A}, \mathrm{B}$, and $\mathrm{C}$ were negative.

The final diagnosis was Sharp syndrome which was considered to be potentially related to the inhalation of scouring powder 5 yrs previously. Initially the patient received prednisolone $60 \mathrm{mg} \cdot \mathrm{day}^{-1}$ for 5 weeks, decreasing the dose to $4 \mathrm{mg} \cdot \mathrm{day}^{-1}$ progressively. Based upon the initial diagnosis of silicoproteinosis, the persistence of $\mathrm{SiO}_{2}$ in the BAL, and the macroscopic characteristics of the fluid, the left lung was lavaged on January 17, 1994 and the right lung on January 24, 1994. Each time, 12 L of normal saline was used. In April 1995, the patient was in good condition without symptoms and the chest radiograph showed a dramatic improvement, with only a mild interstitial basilar infiltration. There was a slight improvement $(10 \%)$ of forced expiratory volume in one second (FEV1). TL,CO remained unchanged. ESR was $33 \mathrm{~mm} \cdot$ day $^{-1}$, LDH $448 \mathrm{IU} \cdot \mathrm{L}^{-1}$ and the CIC level had returned to normal.

\section{Discussion}

The frequency of acute or chronic diseases following inhalation of scouring powder may be underestimated. Acute silicosis in workers in abrasives factories have been described since 1929 [3]. Other cases are wellknown after sandblasting [4], due to inadequate personal protective equipment. Rarely, silicosis due to intentional inhalation has been described in acute or subacute silicosis $[1,5]$, or in a chronic context $[2,6]$. Surprisingly, the present patient who presented with an acute silicosis and who improved on corticotherapy developed a chronic disease.

Clinical and serological autoimmune manifestations have been described with a high prevalence in persons chronically exposed to silica in a factory producing scouring powder [7]. Autoimmune processes were present in
$32(64 \%)$ of the 50 subjects studied. Likewise, in a mortality study of gold miners exposed to silica, a multiple cause analysis revealed a significant excess of arthritis, and musculoskeletal disease (including systemic lupus and sclerosis) [8], and another study has confirmed the association of silicosis and rheumatoid arthritis [9]. As a consequence of the study by HAUSTEIN and ZIEGLER [10], scleroderma is acknowledged as an occupational disease, not only in cases with associated silicosis but also in cases with high level silica exposure without overt silicosis. Finally, a case of occupational progressive systemic sclerosis due to inhalation of scouring powder has been reported in a cleaning woman [11]. Our patient consulted us when she developed Sharp's syndrome 3 yrs after acute manifestations of silicosis. The difficulty in establishing the initial diagnosis was twofold: firstly, it required a mineral analysis of a biopsy specimen or BAL. Indeed, the range of the ratio of particles detected by scanning electron microscopy (SEM) as compared to light microscopy may vary from near unity up to 1,000 [12]. Therefore, electronmicroscopic analytical techniques are much more useful $[13,14]$ if pneumoconiosis is suspected. Secondly, the reluctance of the patient to admit this type of intoxication, which may explain why the syndrome has not been described.

From a physiopathological point of view, silica probably induces alveolar proteinosis by an initial toxic effect on alveolar macrophages. Indeed, scouring powder (Ajax) contains up to $95 \%$ silica, $2 \%$ alkylbenzosulphonate and $3 \%$ trichlorocyanuric acid (personal communication of Colgate Palmolive, France). Alveolar proteinosis caused by chemical agents, such as busulfan and carmustine has been reported [15], but never by those additives which are present at low concentration in scouring powder.

Macrophages play a prominent role in lung inflammation by producing radicals, enzymes, arachidonic acid metabolites and cytokines [16]. In silicosis, a large influx of mononuclear phagocytes occurs with an increased production of oxidants, fibronectin, neutrophil chemotactic factor, interleukin-6 (IL-6) and tumour necrosis factor- $\alpha$ (TNF- $\alpha)$ [17]. IL-6 is a pluripotent immunomodulatory cytokine which involved in the pathogenesis of inflammatory and autoimmune diseases, including rheumatoid arthritis and systemic lupus erythematosus [18].

From a therapeutic point of view, we decided on a combined treatment of corticosteroid therapy and pulmonary lavage. The latter was performed because the pathological examination revealed macrophagic and lipoid alveolitis, with zones of alveolar proteinosis. Later on BAL confirmed the presence of silica. In alveolar proteinosis, the therapeutic value of pulmonary lavage is well-established $[19,20]$. The role of this therapy should be considered in the improvement of autoimmune diseases of the lung. Indeed, alveolitis characterized by activated macrophages may be partly responsible for the systemic disease.

In conclusion, when confronted with pulmonary interstitial syndrome, and even more so when associated with mixed connective tissue disease, the history should include questions about possible occupational exposure to common household products, such as scouring powder. Microanalysis may help to establish the diagnosis. 


\section{References}

1. Dumontet C, Biron F, Vitrev D, et al. Acute silicosis due to inhalation of a domestic product. Am Rev Respir Dis 1991; 143: 880-882.

2. Gong H, Tashkin DP. Silicosis due to intentional inhalation of abrasive scouring Powder. Am J Med 1979; 67: 358-362.

3. Middleton EL. The present position of silicosis in industry in Britain. Br Med J 1929; 2: 485-492.

4. Suratt PM, Winn WC, Brody AR, Bolton AR. Giles RD. Acute silicosis in tombstone sandblasters. Am Rev Respir Dis 1977; 115: 521-529.

5. Vincent M, Arthaud Y, Crettet G, et al. Silicose aigûe fatale par inhalation volontaire de poudre à récurer. Rev Mal Respir 1995; 12: 499-503.

6. Casassus P, Boissonnas A., Luschevici V, Laroche SL. Silicose par toxicomanie à une poudre à récurer. Press Méd 1980; 9: 190-191.

7. Sanchez-Roman J, Wichmann I, Salaberri J, Valera JM, Nunez-Roldan A. Multiple clinical and biological autoimmune manifestations in 50 workers after occupational exposure to silica. Ann Rheum Dis 1993; 52: 534-548.

8. Steenland K, Brown D. Mortality study of gold miners exposed to silica and nonasbestiform amphibole minerals: an update with 14 more years of follow-up. Am J Ind Med 1995; 27: 217-229.

9. Rosenmann KD, Zhu Z. Pneumoconiosis and associated medical conditions. Am J Ind Med 1995; 27: 107-113.

10. Haustein UF, Ziegler V. Environmentally-induced systemic sclerosis-like disorders. Int J Dermatol 1985; 24: 147-151.
11. Melhorn VJ, Gerlach CH, Ziegler V. Berufsbedingte progressive systemische Sklerodermie durch einquarzhaltiges Scheuermittel. Dermatosen 1990; 38: 180-184.

12. Abraham JL, McEuen DD. Inorganic particulates associated with pulmonary alveolar proteinosis: SEM and X-ray microanalysis results. Appl Pathol 1986; 4: 138-146.

13. Seaton A, Legge JS, Henderson J, Kerr KM. Accelerated silicosis in Scottish stonemasons. Lancet 1991; 337 : 341-344.

14. Nugent KM, Dodson RF, Idell S, Devillier JR. The utility of bronchoalveolar lavage and transbronchial lung biopsy combined with energy-dispersive X-ray analysis in the diagnosis of silicosis. Am Rev Respir Dis 1989; 140: $1438-1441$

15. Lehne G, Lote K. Pulmonary toxicity of cytotoxic and immunosuppressive agents. Acta Oncologica 1990; 29: 113-124.

16. Lohmann-Matthes ML, Steinmüller C, Franke-Ullmann G. Pulmonary macrophages. Eur Respir J 1994; 7: $1678-1689$.

17. Vanhée D, Gosset P, Boitelle A, Wallaert B, Tonel AB. Cytokines and cytokine network in silicosis and coal workers pneumoconiosis. Eur Respir J 1995; 8: 834-842.

18. Crestani B, Seta N, De Bandt M, et al. Interleukin-6 secretion by monocytes and alveolar macrophages in systemic sclerosis with lung involvement. Am J Respir Crit Care Med 1994; 149: 1260-1265.

19. Ramirez J. Alveolar proteinosis: Importance of pulmonary lavage. Am Rev Respir Dis 1971; 103: 667-677.

20. Danel C, Israël-Biet D, Costabel U, Klech H. Therapeutic applications of bronchoalveolar lavage. Eur Respir $J$ 1992; 5: 1173-1175. 